Research Paper

\title{
Relationship between Serum Level of Lymphatic Vessel Endothelial Hyaluronan Receptor-I and Prognosis in Patients with Lung Cancer
}

Keiko Nunomiya, Yoko Shibata ${ }^{\bowtie}$, Shuichi Abe, Sumito Inoue, Akira Igarashi, Keiko Yamauchi, Tomomi Kimura, Yasuko Aida, Takako Nemoto, Masamichi Sato, Hiroyuki Kishi, Hiroshi Nakano, Kento Sato, Isao Kubota

Department of Cardiology, Pulmonology, and Nephrology,Yamagata University School of Medicine, 2-2-2 Iida-Nishi, Yamagata 990-9585, Japan.

$\triangle$ Corresponding author: Dr. Yoko Shibata, 2-2-2 Iida-Nishi, Yamagata City, Yamagata 990-9585, Japan. Telephone: +81-23-628-5302 Fax: +81-23-628-5305 Email: shibata@med.id.yamagata-u.ac.jp.

(C) Ivyspring International Publisher. This is an open-access article distributed under the terms of the Creative Commons License (http://creativecommons.org/ licenses/by-nc-nd/3.0/). Reproduction is permitted for personal, noncommercial use, provided that the article is in whole, unmodified, and properly cited.

Received: 2014.0I.04; Accepted: 2014.02.23; Published: 20I4.03.II

\begin{abstract}
Background: Lymphatic vessel endothelial hyaluronan receptor-I (LYVE-I) is a hyaluronic acid receptor that is selectively expressed in the endothelia of lymphatic capillaries. The density of lymphatic vessels expressing LYVE-I on immunohistochemistry negatively correlates with prognosis of patients with non-small-cell lung cancer. However, the relationship between LYVE-I serum levels and lung cancer staging is unknown.

Methods: We collected blood samples from 58 lung cancer patients before treatment and measured LYVE-I serum levels using an enzyme-linked immunosorbent assay.

Results: Mean serum LYVE-I levels were I,420 pg/mL. Serum LYVE-I levels correlated positively with serum albumin levels, but inversely with primary tumor size, leukocyte counts, and platelet counts by Pearson's product-moment correlation coefficient. A high cancer staging, occurrence of lymph-node metastases, and occurrence of distant metastases were significantly associated with low LYVE-I levels. Moreover, multiple logistic regression analyses revealed that LYVE-I levels were predictive of the presence of lymph node and distant metastases, independently of the other factors. Kaplan-Meier analysis showed that the survival of patients with serum LYVE-I $\leq 1,553$ $\mathrm{pg} / \mathrm{mL}$ was significantly poorer than that of patients with serum LYVE-I $>1,553 \mathrm{pg} / \mathrm{mL}$. This survival difference relative to LYVE-I levels remained statistically significant after adjusting for age and gender by the Cox proportional-hazard analysis.

Conclusion: Serum LYVE-I is significantly low in lung cancer patients with metastasis, compared with those without. Measuring LYVE-I levels in lung cancer patients may be useful for evaluating lung cancer progression.
\end{abstract}

Key words: lung cancer; LYVE-1; metastasis; survival; biomarker.

\section{Introduction}

Lung cancer is one of the most common cancers and cause of cancer-related deaths worldwide [1, 2] because of its extremely poor prognosis. Approximately 82.6 (male) and 30.1 (female) per 100,000 people die each year due to lung cancer in Japan [3]. Lung cancer treatment regimens are determined by the histological type and staging of cancer and patients' performance status. Lung cancer staging is determined in accordance with the TNM classification. TNM classification is based on the size of primary tumor, lymph node metastases, and distant metastases $[4,5]$. TNM classification of lung cancer is usually 
assessed by complementary radiological examinations such as chest X-ray, computed tomography, positron emission tomography-computed tomography, bone scintigraphy, and brain magnetic resonance imaging [4].

Levels of some serum markers associated with lung cancer often correlate with disease progression or therapeutic response [6-11]. These markers include carcinoembryonic antigen (CEA), cytokeratin 19 fragments (CYFRA 21-1), squamous cell carcinoma antigen (SCC), pro-gastrin-releasing peptide (Pro-GRP), and neuron-specific enolase (NSE) [12-14]. However, because serum levels of the abovementioned markers often go up in benign disorders or other cancers [10,13,15-24], but do not increase in early cancer stages [9-11], their potential diagnostic sensitivity or specificity is almost always insufficient. Therefore, tumor markers are indicated for monitoring therapeutic effects, recurrence surveillance, or for presuming histological subtypes of cancer, but not for lung cancer detection $[7,8,25,26]$.

Lymphatic vessel endothelial hyaluronan receptor-1 (LYVE-1) is a hyaluronic acid receptor, a 322-residue protein belonging to the integral membrane glycoproteins [27, 28]. LYVE- 1 is mainly expressed in the endothelium of lymphatic capillaries $[27,28]$. It is also expressed in lymphatic vessels associated with several other cancers or tumors [29-40].

Reportedly, immunohistochemical intensity of LYVE-1 expression is useful for detecting lymphatic invasion or lymphangiogenesis [29-40]. Lymphatics density assessed by LYVE-1 immunohistochemistry was correlated with patients' prognosis in non-small-cell lung cancer [39]. However, the relationship between circulating LYVE-1 levels and cancer progression has not been investigated. Furthermore, whether LYVE-1 can serve as a biomarker for evaluating prognosis of lung cancer patients is not understood.

In this study, we examined serum LYVE-1 levels in lung cancer patients and investigated the relationship between serum LYVE-1 levels and disease progression in lung cancer patients.

\section{Methods}

\section{Patients}

This study enrolled 58 lung cancer in-patients before treatment in the Yamagata University Hospital from October 2008 to March 2011. Patients were excluded if they had double lung cancers, had already received lung cancer treatment, or had acute inflammatory diseases such as pneumonia. The study was approved by the institutional ethics committee and all patients provided written informed consent forms.
We collected blood samples by peripheral phlebotomy. Samplings were always performed in the early morning on the second day after admission to the hospital, and the same procedures were followed for all sample collections. Samples were centrifuged at 3,000 rpm for $15 \mathrm{~min}$ at $4{ }^{\circ} \mathrm{C}$, transferred to pre-chilled tubes, and stored at $-80^{\circ} \mathrm{C}$. LYVE- 1 serum levels were measured using an ELISA kit (human LYVE-1 Duoset, DY2089, R\&D SYSTEMS, Minneapolis, MN, US) following manufacturer's instructions. Patients' clinical and medical records were used to classify each patient according to the guidelines of the Japan Lung Cancer Society [5].

\section{Statistical analyses}

Data are presented as means \pm SD or medians (interquartile range). Correlations between serum LYVE-1 levels and continuous data were calculated using Pearson's product-moment correlation coefficient. Student's $t$-test and analysis of variance (ANOVA) were performed to compare serum LYVE-1 levels among categorical data. Multivariate logistic regression analyses were performed to investigate whether LYVE-1 levels were predictive for lymph node or distant metastases. Kaplan-Meier method was used to evaluate overall survival according to cutoff serum LYVE-1 level in all participants. Overall survival was defined as the time from diagnosis to death or the last follow-up date. To estimate whether LYVE-1 serum levels were associated with overall survival, univariate and multivariate Cox proportional-hazard analyses were performed. All statistical analyses were performed using the software, JMP version 9 (SAS Institute Inc., Cary, NC, USA). Statistical significance was inferred for differences with $P$ values $<0.05$.

\section{Results}

Mean serum LYVE-1 levels were 1,420 \pm 304 $\mathrm{pg} / \mathrm{mL}$; serum LYVE-1 levels were normally distributed. Patients' characteristics are summarized in Table 1 . The mean age of patients was $71.3 \pm 8.2$ years.

Table 2 compares LYVE-1 levels according to patients' gender, pathological type, clinical disease staging, smoking history, and presence of symptoms, lymph-node metastases, or distant metastases. Twenty-seven patients had adenocarcinoma, 12 had squamous cell carcinoma, and one had adenosquamous carcinoma in the non-small-cell lung cancer group. Serum LYVE-1 levels were significantly lower in subjects with lymph node or distant metastases than in those without. LYVE-1 serum levels were lowest in patients with stage-4 lung cancer. One male adenocarcinoma patient had an epidermal growth factor receptor (EGFR) mutation. He was treated with 
an EGFR tyrosine kinase inhibitor and the characteristics of his case were as follows: his age was 62 years at diagnosis, he had never smoked, he had stage IV disease, his survival time was 27 months, and his serum LYVE-1 was 1,708 pg/mL. Correlations between parameters (explanatory variables) and serum LYVE-1 levels (dependent variable) are shown in Table 3. LYVE-1 serum levels positively correlated with albumin serum levels, and inversely correlated with primary tumor size, leukocyte counts, and platelet counts.

To investigate whether LYVE-1 levels were predictive of lymph node or distant metastases, multivariate logistic regression analyses were performed. As shown in Table 4, LYVE-1 levels were predictive of both lymph node and distant metastases independently of primary tumor size (Table 4). The receiver-operating characteristic (ROC) curve analysis was used to determine the best LYVE-1 cut-off levels for discriminating the existence of distant metastases. As shown in Figure 1, the best corresponding cut-off of LYVE-1 was $1,553 \mathrm{pg} / \mathrm{mL}$ with area-under-the-curve of 0.752 , sensitivity of 0.962 , and specificity of 0.484 . Based on this cut-off value, we performed the Kaplan-Meier analysis to estimate patient's overall survival. One patient was excluded from this analysis because non-related cancer death. Overall 3-year survival rates of patients with high versus low LYVE-1 levels were $71.3 \%$ and $39.8 \%$, respectively (high, LYVE-1 > 1,553 pg/mL; low, LYVE-1

Table 2. Comparisons of serum LYVE-I levels.

\begin{tabular}{lllll}
\hline Variables & Categories & No. & LYVE-1 $(\mathrm{pg} / \mathrm{mL})$ & $P$ value \\
\hline Gender & male & 50 & $1,405 \pm 310$ & 0.372 \\
female & 8 & $1,510 \pm 265$ & \\
Histological & NSCLC & 40 & $1,466 \pm 314$ & 0.172 \\
type & & & & \\
Stage & SCLC & 14 & $1,340 \pm 214$ & \\
& I & 11 & $1,742 \pm 211$ & 0.0001 \\
& II & 9 & $1,398 \pm 267$ & \\
Smoking his- & III & 11 & $1,426 \pm 383$ & \\
tory & never & 7 & $1,622 \pm 219$ & 0.167 \\
& & & & \\
Symptoms & ex & 24 & $1,398 \pm 355$ & \\
& current & 26 & $1,381 \pm 263$ & \\
N stage & present & 26 & $1,515 \pm 325$ & 0.029 \\
& 0 & 32 & $1,342 \pm 266$ & \\
M stage & $\geq 1$ & 35 & $1,547 \pm 308$ & 0.009 \\
& 0 & 31 & $1,530 \pm 329$ & 0.0009 \\
& 1 & 26 & $1,272 \pm 190$ & \\
\hline
\end{tabular}

Serum LYVE-1 levels were compared in each group according to gender, histological type, stage, smoking history, presence of symptoms, lymph node metastasis, and distant metastasis. Data are presented as $n$, mean $\pm \mathrm{SD}$. Differences in gender, histological type, symptoms, lymph-node metastasis, and distant metastasis were evaluated by Student's t-test, except for stage and smoking history, where analysis of variance was used. Abbreviations: LYVE-1, lymphatic vessel endothelial hyaluronan receptor-1; NSCLC, non-small-cell lung cancer; SCLC, small-cell lung cancer; N, lymph-node metastasis; M, distant metastasis. $\leq 1,553 \mathrm{pg} / \mathrm{mL} ; P=0.021$, log-rank test, $P=0.017$, Wilcoxon test; Figure 2). In univariate Cox proportional-hazard analysis, low LYVE-1 levels were significantly associated with low overall survival (Table 5 , upper panel). This association remained significant after adjusting for age and gender (Table 5, lower panel).

Table I. Characteristics of patients $(n=58)$

\begin{tabular}{ll}
\hline Variables & $\begin{array}{l}\text { Mean } \pm \text { SD or median (in- } \\
\text { terquartile range) }\end{array}$ \\
\hline LYVE-1 $(\mathrm{pg} / \mathrm{mL})$ & $1,420 \pm 304$ \\
Age (years) & $71.3 \pm 8.2$ \\
Primary tumor size $(\mathrm{mm})$ & $33(25-54)$ \\
Brinkman index (cigarette × years) & $980(500-1,433)$ \\
$\mathrm{TP}(\mathrm{g} / \mathrm{dL})$ & $6.7(6.2-7.0)$ \\
$\mathrm{Alb}(\mathrm{g} / \mathrm{dL})$ & $3.7(3.1-4.0)$ \\
$\mathrm{ALT}(\mathrm{IU} / \mathrm{L})$ & $19(14-27)$ \\
$\mathrm{LDH}(\mathrm{IU} / \mathrm{L})$ & $201(177-242)$ \\
$\mathrm{sCr}(\mathrm{mg} / \mathrm{dL})$ & $0.73(0.66-0.91)$ \\
$\mathrm{CRP}(\mathrm{mg} / \mathrm{dL})$ & $0.46(0.10-5.73)$ \\
$\mathrm{WBC}(/ \mu \mathrm{L})$ & $6,690(5,300-8,603)$ \\
$\mathrm{Hb}(\mathrm{g} / \mathrm{dL})$ & $12.6(11.1-14.0)$ \\
Plt $\left(\times 10^{3} / \mu \mathrm{L}\right)$ & $240(172-326)$ \\
CYFRA $21-1(\mathrm{ng} / \mathrm{mL})$ & $2.7(1.5-7.4)$ \\
$\mathrm{CEA}(\mathrm{ng} / \mathrm{mL})$ & $4.63(2.36-8.96)$ \\
Pro-GRP $(\mathrm{pg} / \mathrm{mL})$ & $43.2(26.1-145.6)$ \\
\hline Dat &
\end{tabular}

Data are presented as mean \pm SD or median (interquartile range).

Abbreviations: LYVE-1, lymphatic vessel endothelial hyaluronan receptor-1; TP, total protein; Alb, albumin; ALT, alanine aminotransferase; $\mathrm{LDH}$, lactate dehydrogenase; $\mathrm{SCr}$, serum creatinine; CRP, C-reactive protein; WBC, white blood cells; Hb, hemoglobin; Plt, platelets; CYFRA 21-1, cytokeratin 19 fragments; CEA, carcinoembryonic antigen; Pro-GRP, pro-gastrin-releasing peptide.

Table 3. Relationships between variables and serum LYVE-I levels.

\begin{tabular}{|c|c|c|}
\hline Variables & $r$ & $P$ value \\
\hline Age & -0.126 & 0.345 \\
\hline Size of primary tumor & -0.417 & 0.003 \\
\hline Brinkman index & -0.098 & 0.472 \\
\hline $\mathrm{TP}$ & 0.027 & 0.843 \\
\hline $\mathrm{Alb}$ & 0.353 & 0.007 \\
\hline ALT & -0.031 & 0.819 \\
\hline LDH & -0.099 & 0.460 \\
\hline $\mathrm{sCr}$ & -0.057 & 0.672 \\
\hline CRP & -0.255 & 0.053 \\
\hline WBC & -0.401 & 0.002 \\
\hline $\mathrm{Hb}$ & 0.252 & 0.056 \\
\hline Plt & -0.286 & 0.029 \\
\hline CYFRA 21-1 & -0.195 & 0.154 \\
\hline CEA & -0.146 & 0.275 \\
\hline Pro-GRP & -0.036 & 0.804 \\
\hline \multicolumn{3}{|c|}{$\begin{array}{l}\text { Correlations between serum LYVE-1 levels and continuous data. } \\
\text { Abbreviations: LYVE-1, lymphatic vessel endothelial hyaluronan receptor-1; TP, total } \\
\text { protein; Alb, albumin; ALT, alanine aminotransferase; LDH, lactate dehydrogenase; } \mathrm{Cr} \text {, } \\
\text { serum creatinine; CRP, C-reactive protein; WBC, white blood celll;; Hb, hemoglobin; Plt, } \\
\text { platelets; CYFRA 21-1, cytokeratin } 19 \text { fragment; CEA, carcinoembryonic antigen; } \\
\text { Pro-GRP, pro-gastrin-releasing peptide; } r \text {, Pearson's product-moment correlation coeffi- } \\
\text { cient. }\end{array}$} \\
\hline
\end{tabular}


Table 4. Multivariate logistic regression analyses of factors predictive for lymph node (Model I) and distant metastases (Model 2)

\begin{tabular}{|c|c|c|c|}
\hline \multicolumn{4}{|l|}{ Model 1} \\
\hline Variables & Odds ratio & $\begin{array}{l}95 \% \text { confidence } \\
\text { interval }\end{array}$ & $\begin{array}{l}\mathrm{P} \\
\text { value }\end{array}$ \\
\hline $\begin{array}{l}\text { size of primary tumor (per } \\
1 \mathrm{~mm} \text { increase) }\end{array}$ & 0.979 & $0.939-1.011$ & 0.220 \\
\hline $\begin{array}{l}\text { LYVE-1 (per } 100 \text { pg/mL } \\
\text { increase) }\end{array}$ & 0.775 & $0.577-0.995$ & 0.045 \\
\hline \multicolumn{4}{|l|}{ Model 2} \\
\hline Variables & Odds ratio & $\begin{array}{l}95 \% \text { confidence } \\
\text { interval }\end{array}$ & $\begin{array}{l}P \\
\text { value }\end{array}$ \\
\hline $\begin{array}{l}\text { size of primary tumor (per } \\
1 \mathrm{~mm} \text { increase) }\end{array}$ & 1.016 & $0.987-1.054$ & 0.296 \\
\hline $\begin{array}{l}\text { LYVE-1 (per } 100 \text { pg/mL } \\
\text { increase) }\end{array}$ & 0.762 & $0.568-0.974$ & 0.029 \\
\hline
\end{tabular}

Table 5. LYVE-I predicted overall survival in lung cancer patients.

\begin{tabular}{llll}
\hline $\begin{array}{l}\text { Unadjusted model } \\
\text { Variables }\end{array}$ & Hazard ratio & $\begin{array}{l}\text { 95\% confidence } \\
\text { interval }\end{array}$ & $P$ value \\
$\begin{array}{l}\text { LYVE-1(per } 100 \mathrm{pg} / \mathrm{mL} \\
\text { increase) }\end{array}$ & 0.802 & $0.682-0.938$ & 0.006 \\
$\begin{array}{l}\text { Adjusted model } \\
\text { Variables }\end{array}$ & Hazard ratio & $\begin{array}{l}95 \% \text { confidence } \\
\text { interval }\end{array}$ & $P$ value \\
$\begin{array}{l}\text { LYVE-1(per } 100 \mathrm{pg} / \mathrm{mL} \\
\text { increase) }\end{array}$ & 0.804 & $0.681-0.941$ & 0.006 \\
$\begin{array}{l}\text { One patient was excluded from these analyses due to death by another cancer type. } \\
\text { Upper: Univariate Cox proportional-hazard analysis. } \\
\text { Lower: Multivariate Cox proportional-hazard analysis adjusted for age and gender. }\end{array}$
\end{tabular}

\section{Discussion}

LYVE-1 is one of the hyaluronan-binding glycoprotein receptors, mainly expressed on lymphatics endothelia. Banerji et al. first identified LYVE-1 by homologue searching of the EST database, using the amino acid sequence of the hyaluronan-binding domain of CD44, containing a single Link module $[27,28]$, the prototypic hyaluronan-binding domain of the Link protein superfamily [27]. Later, using flow cytometry and fluorescence microscopy, Prevo et al. demonstrated that human $293 \mathrm{~T}$ cells, transfected with full-length LYVE-1, bound and internalized hyaluronan in vitro [41], providing clues as to the LYVE-1 function. In vivo, although it is unclear whether LYVE-1 actually circulates in blood in an intact form, large ectodomain LYVE-1 fragments were identified in normal plasma by western blotting and ELISA [42]. Accordingly, we were able to measure circulating

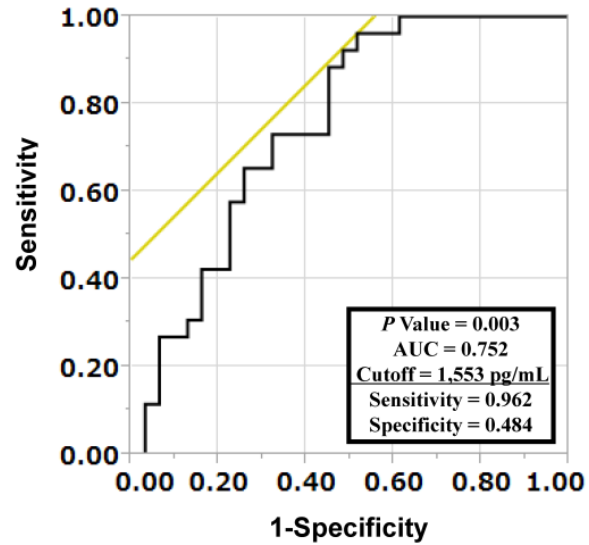

Figure I. Determination of cut-off serum LYVE-I levels for discriminating occurrences of distant metastases in lung cancer patients. A receiver-operating characteristic (ROC) curve analysis was performed to determine the cut-off LYVE-I level for discriminating the existence of distant metastases. The area under the curve (AUC) was 0.752 and the cut-off value was $1,553 \mathrm{pg} / \mathrm{mL}$, with a sensitivity of 0.962 and a specificity of 0.484 .

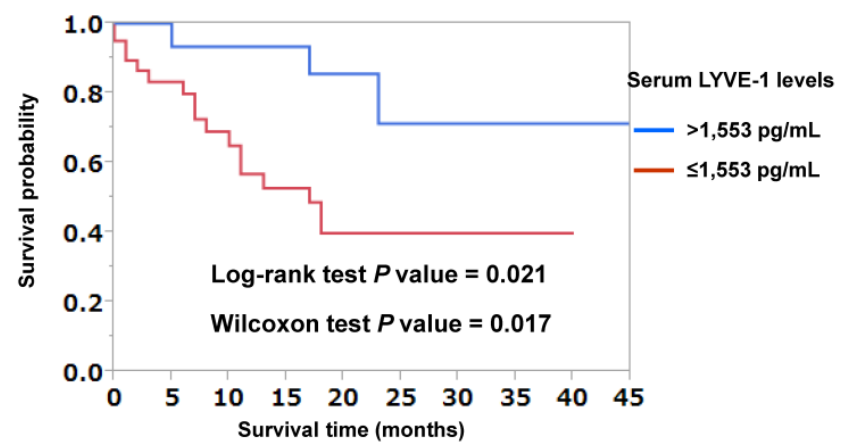

Figure 2. Kaplan-Meier curves analyzing the probability of survival in patients with lung cancer, based on LYVE-I cut-off used for discriminating the existence of distant metastases. Kaplan-Meier analysis was performed to calculate overall survival for lung cancer patients with LYVE-I $>1,553 \mathrm{pg} / \mathrm{mL}$ and those with $\leq 1,553 \mathrm{pg} / \mathrm{mL}$. One patient was excluded from this analysis due to death by another cancer type. Patients' 3-year overall survival rate with LYVE-I $>1,553 \mathrm{pg} / \mathrm{mL}$ and $\leq 1,553 \mathrm{pg} / \mathrm{mL}$ were $71.3 \%$ and $39.8 \%$, respectively. There was a significant difference in prognosis between patients with LYVE-I $>I, 553 \mathrm{pg} / \mathrm{mL}$ and those with $\leq 1,553 \mathrm{pg} / \mathrm{mL}$ by log-rank test $(P=0.02 \mathrm{I})$ and Wilcoxon test $(P=0.017)$.

LYVE-1 in this study, suggesting that LYVE-1 expressed on the lymphatic endothelia may be shed and subsequently released into the circulation. Thus, we report that serum LYVE-1 levels were significantly lower in lung cancer patients showing lymph node or distant metastases than in those without metastasis (Table 2). We also found that serum LYVE-1 levels inversely correlated with primary tumor size (Table 3) and were significant predictors of lymph node and distant metastases (Table 4). Moreover, lung cancer patients with lower serum LYVE-1 levels had poorer prognosis than those with higher serum LYVE-1 levels (Figure 2 and Table 5).

To date, association of LYVE-1 with malignant tumors had been studied using immunohistochemistry. LYVE-1 was thus located distinctly in lymphatic vessels but not blood vessels. Therefore, LYVE-1 is recognized as a specific marker for lymphatic endothelium and LYVE-1 immunostaining had been used 
to search for lymphatic metastases and lymphangiogenesis in various types of cancers, including pulmonary, lingual, mammary, gastric, colon, endometrial, and testicular cancers, and neuroblastomas and vascular tumors [29-40]. However, serum LYVE-1 levels had not been documented in malignant patients. Ramini et al. measured LYVE-1 levels in protein extracts of neuroblastoma tissues using the same ELISA kit we used [38]. To our knowledge, the present study is the first report investigating the relationship between lung cancer staging and LYVE-1 level in serum from those patients.

We measured serum LYVE-1 levels also in patients who were suspected to have lung cancer but were denied having any cancers by further examination (total $\mathrm{n}=9$ ). Their final diagnoses were old inflammatory nodules $(n=6)$, pericardial cyst $(n=1)$, pulmonary hamartoma $(\mathrm{n}=1)$, and foreign-body granuloma without systemic inflammation $(n=1)$. In the above patients, serum LYVE-1 levels were 1,789 \pm $97 \mathrm{pg} / \mathrm{mL}$, which was higher than those of patients with lung cancer. These data were excluded from our Results because they were irrelevant to cancer cases.

In our study, serum LYVE-1 levels were found to be low in lung cancer patients with metastasis and tended to decrease even further with advancing disease stages. Several studies have reported high hyaluronan synthesis in stromal and tumor cells concurrent with high growth factor and cytokine activities in certain pathological conditions such as inflammation and tumor progression, respectively [43]. Chow et al. demonstrated that cytokines and growth factors such as epidermal growth factor and interleukin-1 $\beta$, alone and/or in combination with transforming growth factor- $\beta 1$, can stimulate hyaluronic acid production in lung adenocarcinoma cell line, A549 [44]. In addition, Du et al. suggested that LYVE-1 enhanced adhesion of HS-578T cells, which highly express hyaluronan, to COS-7 cells transfected with LYVE-1 [45]. Ito et al. showed presence of high hyaluronan levels on the surface of highly metastatic mouse mammary carcinomas and its stroma, and mammary carcinoma cells invading the lymphatics expressed high LYVE-1 via hyaluronic acid in vivo [46]. We first hypothesized that hyaluronan-associated LYVE-1 was no longer detectable by the ELISA kit that we used. However, the serum hyaluronan levels did not differ significantly between patients with stage I, II, III, and IV lung cancer (Stage I, $66.5 \pm 26.1 \mathrm{ng} / \mathrm{mL}$; stage II, $82.5 \pm 67.2$ $\mathrm{ng} / \mathrm{mL}$; stage III, $86.1 \pm 97.7 \mathrm{ng} / \mathrm{mL}$; stage IV, $49.1 \pm$ $15.7 \mathrm{ng} / \mathrm{mL}$; $=0.660)$. Accordingly, this initial hypothesis appears to be unlikely. A second possible explanation for the low serum level of LYVE-1 may be the inhabitation of LYVE-1 shedding from lymph vessels in patients with advanced lung cancer. How- ever, because tumor-associated macrophages produce matrix metalloproteinases that can shed extracellular domain of cell surface protein [48, 49], reduction of LYVE-1 shedding does not seem to be a reasonable explanation. A third possible explanation may be the enhancement of LYVE-1 internalization in the lymphatic endothelial cells of patients with lung cancer. Johnson and colleagues demonstrated that lymphatic endothelial cells internalize LYVE-1 by stimulation with tumor necrosis factor (TNF)- $\alpha$ and TNF- $\beta$, independently of hyaluronan [47]. Since the serum level of TNF-a is elevated in patients with advanced lung cancer [48], internalization of LYVE-1 may be enhanced in lymphatic endothelial cells, resulting in lower LYVE-1 levels in the serum of patients with cancer. A fourth possible explanation may be the enhanced degradation rate of serum LYVE-1 in patients with lung cancer. To our knowledge, the degradation pathway of serum LYVE-1 has not been investigated. However, the degradation rate of serum LYVE-1 may be upregulated according to the elevation of circulating proteases in patients with lung cancer, shortening the half-life of serum LYVE-1 [49].

Our study had some limitations. First, we did not perform LYVE-1 immunostaining in tumors or lymph nodes. This was limited by the extent of collected samples. Almost all patients were diagnosed using bronchoscopy or some by sputum or pleural effusion cytology. Only three patients were diagnosed by pulmonary lobectomy. Therefore, the extent of biopsy specimens precluded immunohistochemical studies. Second, we did not measure cytokine levels in patients' blood samples. Cytokine levels likely undergo changes in relation to serum LYVE-1 levels in lung cancer patients. Third, we only measured serum LYVE-1 levels in lung cancer patients before treatment, not after. It will be necessary to verify temporal effects of therapy on serum LYVE-1 levels.

Lung cancer is diagnosed by radiological imaging. Because LYVE-1 levels were significantly associated with staging and prognosis of lung cancer patients, measuring LYVE-1 levels may be useful in predicting occurrences of metastases and patients' survival. Thus, serum LYVE-1 levels are significantly associated with disease progression in lung cancer patients.

\section{Abbreviations}

Area under the curve, AUC; carcinoembryonic antigen, CEA; cytokeratin 19 fragments, CYFRA 21-1; lymphatic vessel endothelial hyaluronan receptor-1, LYVE-1; neuron-specific enolase, NSE; pro-gastrin-releasing peptide, Pro-GRP; receiver-operating characteristic, ROC; squamous cell carcinoma antigen, SCC. 


\section{Acknowledgements}

We thank Emiko Nishidate and Eiji Tsuchida for their excellent technical assistance.

\section{Funding}

This study was supported by the Japan Society for the Promotion of Science (19590880, 20590892, and 23390220).

\section{Ethics committee approval}

This study was approved by the Institutional Ethics Committee of Yamagata University School of Medicine. All participants provided written informed consents.

\section{Conflicts of interest}

The authors declare no competing interests.

\section{References}

1. Longo DL. Approach to the Patient With Cancer. In: Longo DL, Fauci AS, Kasper DL, Hauser SL, Jameson JL et al., editors. Harrison's Principles of Internal Medicine; 18th ed. New York, USA: McGraw-Hill Professional; 2011: 646-54.

2. Siegel R, Naishadham D, Jemal A. Cancer statistics, 2013. CA Cancer J Clin 2013; 63: 11-30.

3. [Internet] Ministry of Health Labor and Welfare Vital Statistics in Japan: The Latest Trends. http://www.mhlw.go.jp/english/database/db-hw/dl/81-1a2en.pdf.

4. Horn L, Pao W, Johoson DH. Neoplasms of the lung. In: Longo DL, Fauci AS, Kasper DL, Hauser SL, Jameson JL et al, editors. Harrison's Principles of Internal Medicine; 18th ed. New York, USA: McGraw-Hill Professional; 2011: 737-53.

5. The Japan Lung Cancer Society. The 7th Eddition of General Rule for Clinical and Pathological Record of Lung Cancer. Tokyo, Japan: Kanehara \& CO.,LTD. 2010.

6. Ardizzoni A, Cafferata MA, Tiseo M, Filiberti R, Marroni P, et al. Decline in serum carcinoembryonic antigen and cytokeratin 19 fragment during chemotherapy predicts objective response and survival in patients with advanced nonsmall cell lung cancer. Cancer 2006; 107: 2842-9

7. Colt HG, Murgu SD, Korst RJ, Slatore CG, Unger M, et al. Follow-up and surveillance of the patient with lung cancer after curative-intent therapy: Diagnosis and management of lung cancer, 3rd ed: American College of Chest Physicians evidence-based clinical practice guidelines. Chest 2013; 143: e437S-54S.

8. Hatzakis KD, Froudarakis ME, Bouros D, Tzanakis N, Karkavitsas N, et al. Prognostic value of serum tumor markers in patients with lung cancer. Respiration 2002; 69: 25-9.

9. Miyake Y, Kodama T, Yamaguchi K. Pro-gastrin-releasing peptide(31-98) is a specific tumor marker in patients with small cell lung carcinoma. Cancer Res 1994; 54: 2136-40.

10. Okamura K, Takayama K, Izumi M, Harada T, Furuyama K, et al. Diagnostic value of CEA and CYFRA 21-1 tumor markers in primary lung cancer. Lung Cancer 2013; 80: 45-9.

11. Wieskopf B, Demangeat C, Purohit A, Stenger R, Gries P, et al. CYFRA 21-1 as a biologic marker of non-small cell lung cancer. Evaluation of sensitivity, specificity, and prognostic role. Chest 1995; 108: 163-9.

12. Harmsma M, Schutte B, Ramaekers FC Serum markers in small cell lung cancer: Opportunities for improvement. Biochim Biophys Acta 2013; 1836: 255-72.

13. Oremek GM, Sauer-Eppel H, Bruzdziak TH. Value of tumour and inflammatory markers in lung cancer. Anticancer Res 2007; 27: 1911-5.

14. Sung HJ, Cho JY. Biomarkers for the lung cancer diagnosis and their advances in proteomics. BMB Rep 2008; 41: 615-25.

15. Alexander JC, Silverman NA, Chretien PB. Effect of age and cigarette smoking on carcinoembryonic antigen levels. Jama 1976; 235: 1975-9.

16. Guo Q, Kang M, Zhang B, Chen Y, Dong X, et al. Elevated levels of CA 19-9 and CEA in pancreatic cancer-associated diabetes. J Cancer Res Clin Oncol 2010; 136: 1627-31.

17. He CZ, Zhang KH, Li Q, Liu XH, Hong Y, et al. Combined use of AFP, CEA, CA125 and CA19-9 improves the sensitivity for the diagnosis of gastric cancer. BMC Gastroenterol 2013; 13: 87

18. Ishizaka N, Ishizaka Y, Toda E, Koike K, Yamakado M, et al. Are serum carcinoembryonic antigen levels associated with carotid atherosclerosis in Japanese men? Arterioscler Thromb Vasc Biol 2008; 28: 160-5.

19. Maestranzi S, Przemioslo R, Mitchell H, Sherwood RA. The effect of benign and malignant liver disease on the tumour markers CA19-9 and CEA. Ann Clin Biochem 1998; 35 ( Pt 1): 99-103.

20. Molina R, Auge JM, Filella X, Vinolas N, Alicarte J, et al. Pro-gastrin-releasing peptide (proGRP) in patients with benign and malignant diseases: comparison with CEA, SCC, CYFRA 21-1 and NSE in patients with lung cancer. Anticancer Res 2005; 25: $1773-8$.

21. Nakata B, Ogawa $Y$, Ishikawa $T$, Ikeda $K$, Kato $Y$, et al. Serum CYFRA 21-1 is one of the most reliable tumor markers for breast carcinoma. Cancer 2000; 89: 1285-90.

22. Nomura F, Koyama A, Ishijima M, Takano S, Narita M, et al. Serum levels of five tumor markers for lung cancer in patients with chronic renal failure. Oncol Rep 1998; 5. 389-92.
23. Nozoe T, Rikimaru T, Mori E, Okuyama T, Takahashi I. Increase in both CEA and CA19-9 in sera is an independent prognostic indicator in colorectal carcinoma. J Surg Oncol 2006; 94: 132-7.

24. Pasanen PA, Eskelinen M, Partanen K, Pikkarainen P, Penttila I, et al. Multivariate analysis of six serum tumor markers (CEA, CA 50, CA 242, TPA, TPS, TATI) and conventional laboratory tests in the diagnosis of hepatopancreatobiliary malignancy. Anticancer Res 1995; 15: 2731-7.

25. Schneider J, Philipp M, Velcovsky HG, Morr H, Katz N. Pro-gastrin-releasing peptide (ProGRP), neuron specific enolase (NSE), carcinoembryonic antigen (CEA) and cytokeratin 19-fragments (CYFRA 21-1) in patients with lung cancer in comparison to other lung diseases. Anticancer Res 2003; 23: 885-93.

26. [Internet] The Japan Lung Cancer Society Lung cancer guidelines in Japan: The Latest Version. http://www.haigan.gr.jp/uploads/photos/320.pdf.

27. Banerji S, Ni J, Wang SX, Clasper S, Su J, et al. LYVE-1, a new homologue of the CD44 glycoprotein, is a lymph-specific receptor for hyaluronan. J Cell Biol 1999; 144: $789-801$.

28. Jackson DG. Biology of the lymphatic marker LYVE-1 and applications in research into lymphatic trafficking and lymphangiogenesis. Apmis 2004; 112: 526-38.

29. Bono P, Wasenius VM, Heikkila P, Lundin J, Jackson DG, et al. High LYVE-1-positive lymphatic vessel numbers are associated with poor outcome in breast cancer. Clin Cancer Res 2004; 10: 7144-9.

30. Gao F, Lu YM, Cao ML, Liu YW, He YQ, et al. Expression and quantification of LYVE-1 in human colorectal cancer. Clin Exp Med 2006; 6: 65-71.

31. Gao Y, Liu Z, Gao F, Meng XY. High density of peritumoral lymphatic vessels is a potential prognostic marker of endometrial carcinoma: a clinical immunohistochemical method study. BMC Cancer 2010; 10: 131

32. Heinzelbecker J, Kempf KM, Kurz K, Steidler A, Weiss C, et al. Lymph vessel density in seminomatous testicular cancer assessed with the specific lymphatic endothelium cell markers D2-40 and LYVE-1: correlation with pathologic parameters and clinical outcome. Urol Oncol 2013; 31: 1386-94.

33. Ishikawa Y, Akishima-Fukasawa Y, Ito K, Akasaka Y, Yokoo T, et al. Histopathologic determinants of regional lymph node metastasis in early colorectal cancer. Cancer 2008; 112: 924-33.

34. Kato T, Prevo R, Steers G, Roberts H, Leek RD, et al. A quantitative analysis of lymphatic vessels in human breast cancer, based on LYVE-1 immunoreactivity. Br J Cancer 2005; 93: 1168-74.

35. Matsumoto N, Mukae S, Tsuda H, Sawada A, Okazaki Y, et al. Prognostic value of LYVE-1-positive lymphatic vessel in tongue squamous cell carcinomas. Anticancer Res 2010; 30: 1897-903.

36. Morita H, Ishikawa Y, Akishima-Fukasawa Y, Ito K, Akasaka Y, et al. Histopathological predictor for regional lymph node metastasis in gastric cancer. Virchows Arch 2009; 454: 143-51.

37. Ozmen F, Ozmen MM, Ozdemir E, Moran M, Seckin S, et al. Relationship between LYVE-1, VEGFR-3 and CD44 gene expressions and lymphatic metastasis in gastric cancer. World J Gastroenterol 2011; 17: 3220-8.

38. Ramani P, Dungwa JV, May MT. LYVE-1 upregulation and lymphatic invasion correlate with adverse prognostic factors and lymph node metastasis in neuroblastoma. Virchows Arch 2012; 460: 183-91.

39. Renyi-Vamos F, Tovari J, Fillinger J, Timar J, Paku S, et al. Lymphangiogenesis correlates with lymph node metastasis, prognosis, and angiogenic phenotype in human non-small cell lung cancer. Clin Cancer Res 2005; 11: 7344-53.

40. $\mathrm{Xu} \mathrm{H}$, Edwards JR, Espinosa O, Banerii S, Jackson DG, et al. Expression of a lymphatic endothelial cell marker in benign and malignant vascular tumors. Hum Pathol 2004; 35: 857-61.

41. Prevo R, Banerji S, Ferguson DJ, Clasper S, Jackson DG. Mouse LYVE-1 is an endocytic receptor for hyaluronan in lymphatic endothelium. J Biol Chem 2001; 276: 19420-30.

42. Jackson DG. Immunological functions of hyaluronan and its receptors in the lymphatics. Immunol Rev 2009; 230: 216-31.

43. Boregowda RK, Appaiah HN, Siddaiah M, Kumarswamy SB, Sunila S, et al. Expression of hyaluronan in human tumor progression. J Carcinog 2006; 5: 2

44. Chow G, Tauler J, Mulshine JL. Cytokines and growth factors stimulate hyaluronan production: role of hyaluronan in epithelial to mesenchymal-like transition in non-small cell lung cancer. J Biomed Biotechnol 2010; 2010: 485468.

45. Du Y, Liu H, He Y, Liu Y, Yang C, et al. The interaction between LYVE-1 with hyaluronan on the cell surface may play a role in the diversity of adhesion to cancer cells. PLoS One 2013; 8: e63463.

46. Ito $Y$, Shibata MA, Otsuki $Y$. Mouse mammary carcinoma cell-invasion into lymphatics via hyaluronic acid. Linnpa-Gaku 2009; 32: 67-70.

47. Johnson LA, Prevo R, Clasper S, Jackson DG. Inflammation-induced uptake and degradation of the lymphatic endothelial hyaluronan receptor LYVE-1. J Biol Chem 2007: 282: 33671-80.

48. De Vita F, Orditura M, Auriemma A, Infusino S, Catalano G. Serum concentrations of proinflammatory cytokines in advanced non small cell lung cancer patients. J Exp Clin Cancer Res 1998; 17: 413-7.

49. Ondo K, Sugio K, Yamazaki K, Yamaguchi M, Yano T, et al. The significance of serum active matrix metalloproteinase-9 in patients with non-small cell lung cancer. Lung Cancer 2004; 46: 205-13. 